
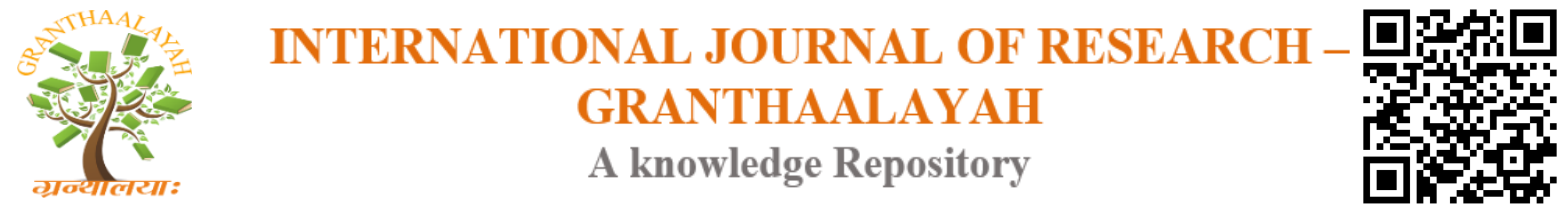

Management

\title{
SOCIO-ECONOMIC EFFECTS OF MICROFINANCE OF GRAMEEN BANK ON BORROWER HOUSEHOLDS IN BOGRA DISTRICT OF BANGLADESH
}

\author{
Md. Abu Shamim *1, Dr. Md. Elias Hossain ${ }^{2}$ \\ ${ }^{* 1}$ M. Phil, Department of Economics, University of Rajshahi, Bangladesh \\ ${ }^{2}$ Professor, Department of Economics, University of Rajshahi, Bangladesh
}

\begin{abstract}
The study is an attempt to examine the socio-economic effects of microfinance of Grameen Bank (GB) on borrower households in the study area. It investigates socio-economic changes occurred among the borrower households in the reference time period. In this regard this study collects required information from 168 respondents in the study area using a structured questionnaire. The collected data were analyzed by using statistical techniques such as descriptive statistics, ANOVA test, Participation Impact Score (PIS) and Standardized Participation Impact Score (SPIS). The ANOVA test is performed to examine the association between microcredit and various socioeconomic factors of borrower households and GB's loan amount. Analysis of the study show that average monthly income, average monthly expenditure, total savings, asset value and other socioeconomic status of borrower households increased after joining the groups of Grameen Bank (GB). The results of PIS or SPIS indicate that 'improved participation in family decision-making' received the highest score among selected 16 items impacts areas while 'increased counting ability' bears the lowest score. In spite of some barriers of GB's microcredit, it has a positive contribution on socio-economic status of the borrower households in terms of increased income generation and improved livelihood of the borrower households.
\end{abstract}

Keywords: Grameen Bank; Microfinance; Socio-economic Impact; Borrower Households.

Cite This Article: Md. Abu Shamim, and Dr. Md. Elias Hossain. (2019). "SOCIO-ECONOMIC EFFECTS OF MICROFINANCE OF GRAMEEN BANK ON BORROWER HOUSEHOLDS IN BOGRA DISTRICT OF BANGLADESH." International Journal of Research - Granthaalayah, 7(5), 137-151. https://doi.org/10.29121/granthaalayah.v7.i5.2019.832.

\section{Introduction}

Microfinance programme is a development scheme for changing socio-economic status of the borrower households in the rural area of Bangladesh. The economy of Bangladesh mainly depends on agriculture, and about 47.3 percent of people of the country are employed in agriculture sector. Currently around 24.63 percent of people live below poverty line in the country and poverty rate is more in rural areas compared to urban areas (BER, 2015). Most of the farmers are marginal and 
small, and they cultivate land under share-cropping system and females are more employed in this sector compared to males (LFS, 2010). However, high rate of unemployment, high dependency ratio, limited income opportunities, low level per capita income, low level of savings, low level of investment, and high rate of poverty are some of the major problems in Bangladesh. Because of these problems, these poor people suffer from malnutrition, and they cannot afford sufficient quantity and nutritious food to eat. In Bangladesh, NGOs have came forward for intervention with their microcredit programmes.

It is revealed that microfinance activities have significant socio-economic impact on the women borrower households. It is observed that microcredit activities increase income levels, stocks and productivity of the enterprise as well as increase expenditure on health and children education (Kireti \& Sakwa, 2014). The availability of financial services for poor households (microfinance) is a significant factor with strong impact on the achievement of the MDGs (Littlefield et al., 2003). The idea of microfinance programme of GB was given initially by Dr. Mohammad Yunus, the Nobel laureate in peace in 2006 and a former Professor of Chittagong University in Bangladesh. In December 1976, with group-based microfinance programmes and Professor Yunus established successfully it as separate bank named the Grameen Bank. It is the Grameen Bank, established in 1976 by Dr. Mohammad Yunus, which operationalized microcredit as the most sensational antipoverty tool for the poorest, particularly for women (Microcredit Summit, 1997). As an immediate outcome, it is found that due to utilization of microcredit, poverty among the people has decreased in Bangladesh (Khan et al., 2017). Thus, different Non-government organizations and Microfinance Institutions (NGO-MFIs) have come ahead with this programme for changing and improving socio-economic state and promote rural development in Bangladesh. The woman folk which constitute half of the total population, have role in domestic duties such washing utensils, cleaning house compounds, livestock and poultry management, feeding of post-harvest activities, guest entertainment, and decision making (Paul and Saadullah, 1991) and they have no access to conventional bank and financial institutions without collateral. If proper training and education by microfinance institutions (MFIs) would be provided for these women, they could be involved in income generating activities. GB gives microcredit to these poor women to defend, diversify, and increase their source of income through enhancing employment opportunities and productivities both in farming and non-farming sectors which contribute to improve socio-economic status and to reduce poverty. However, there are some mixed outcomes of microcredit programmes which often come under criticism and there have been debates as well with regard to its socio-economic effects on the borrower households. Therefore, this study is an effort to examine the socioeconomic effects of GB microfinance on borrower households in Bogra district of Bangladesh.

\section{Brief Literature Review}

A number of earlier studies have been carried out on the socio-economic effects of microcredit programmes on respondent households in the context of Bangladesh and abroad. These studies have shown a linkage between microfinance and socio-economic status of the borrower households. Patient et al. (2016) analyzed the effect of microfinance services on women socio economic development. They showed that assets, income generation and savings are main factors of women's social and economic development and microcredit, savings and training are empowerment tools which have positive impact on their social and economic betterment. Labani et al., (2015) found the socio-economic impacts of Grameen Bank income generating loans on rural women in the study area. It is seen that most of borrower households are employed in farming, 
petty business, livestock rearing, tailoring and van or rickshaw pulling. Clement (2010) explored the socio-economic effect of borrower households. The findings of the study show that SUMI microenterprise has a significant contribution to increasing income, asset, to access to better health care and to improve education, household condition and better clothing in terms of loan takers compared to non-takers. Haque et al., (2016) \& Reji, (2009) explored the socio-economic impact of microcredit on rural areas in Bangladesh. It is found that microcredit has a contribution to socioeconomic changes on rural poor people including the reduction of income inequality, unemployment and increase savings and expenditure. Dzisi \& Obeng, (2013) explored the linkage between microfinance and the socio-economic wellbeing of women entrepreneurs in the study. The findings of the study show that women's enterprises have expanded their business while the socio-economic status of borrower households has also improved after joining in MFIs. Alcivar (2014) explained the social and economic impact of microfinance in the study area. Findings of the study reveal that microfinance activities improve more micro-enterprises and it helps to more informal to become formal businesses. (Kireti \& Sakwa, 2014) examined the socio-economic effects of women participation in microfinance programme. The study shows that microcredit activities increase income levels, increase stocks and productivity of the enterprise as well as increase expenditure on health and children education. Luyirika (2010) critically examines what the role of microfinance in socio-economic status of women in a community. He used both qualitative and quantitative methods. It is found that MIFs provide skills development programme through training, insured credit facilities, savings mobilization, banking facilities, supervision and monitoring of the borrowers and provision of agriculture inputs such as seeds and chemicals but small amount of loan disbursed, high interest rate and low returns on investment. Saad et al., (2014) \& Alam et al., (2014) conducted the socio-economic effects of microfinance on agriculture sector. It is found that microfinance scheme has a contribution to reduce poverty and to improve their standard living among small farmers. It improves and increases the production of the farmers through reinvestment. Based on above the brief literature review it is indicated that microcredit service has a positive contribution to improve socio-economic status of the borrower households.

\subsection{Conceptual Framework}

Based on the brief earlier literature review, it is shown a relationship between microfinance and socio-economic effect of borrower households that is presented in Figure 1.1. Socio-economic effects of microfinance on borrower households are found a net change which indicates a change of economic status between before joining in GB and present.

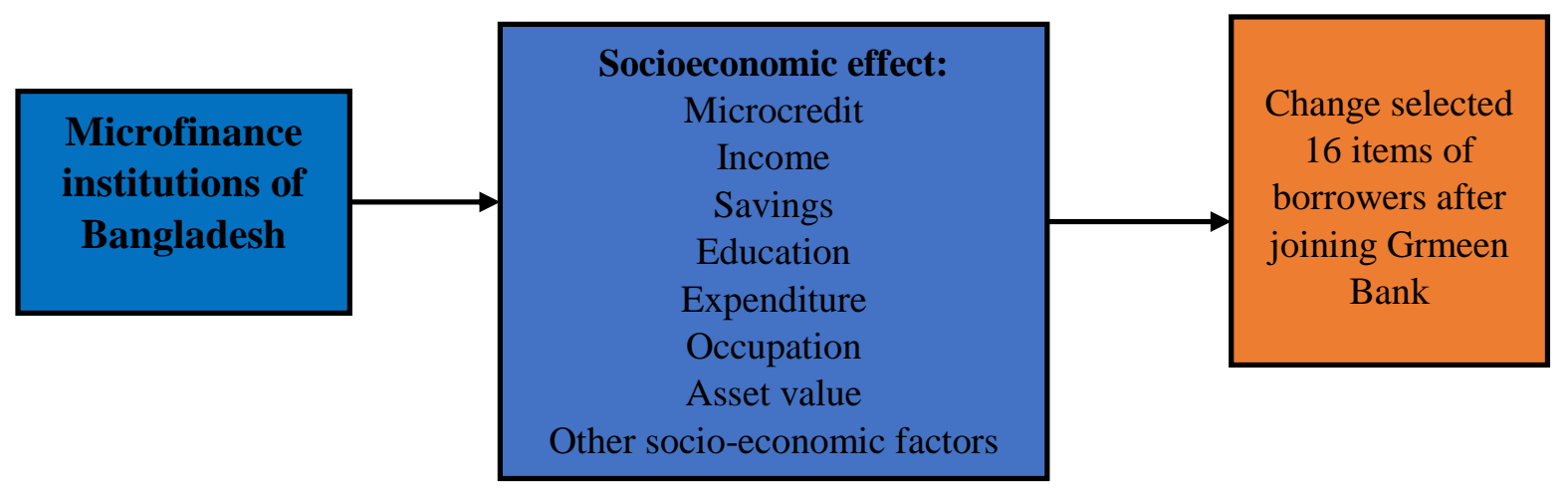

Figure 1.1: Conceptual Framework 


\section{Hypothesis of the Study}

$\mathrm{H}_{0}$ : There is no significant effect between microcredit loan and the socio-economic status of borrower households in the study area.

$\mathrm{H}_{1}$ : There is significant effect between microcredit loan and the socio-economic status of borrower households in the study area.

\section{Research Methodology}

In this study of research methodology, section 4.1 and section 4.2 discuss the selection of study area, and research materials and methods, respectively, which presents as below

\subsection{Selection of Study Area}

The selection of study area is most of the important part for any the study. Bogra district was established in 1821 during the British rule and its area is $2898.68 \mathrm{~km}^{2}$ (1119.18 sq. miles). According to 2011 census, the total population of the district was 3400874 of which 1708806 are males and 1692068 are females. The area of district is $2,898.68 \mathrm{~km}^{2}$ of land (1119.19 sq mi). As study area Bogra district has been selected. Multi-cluster sample has been used in case of selected study area. The district has twelve sub-districts (upazilas) and where Dhunat, Gabtali, Nandigram and Sarikandi upazila among them have been selected randomely. At first, Bogra zone among forty zones of Grameen Bank has been selected, purposively, which fells only Bogra district. Secondly, two areas in six areas under this zone have been selected. Name of these areas is Bogra (sadder) and Dupchachia area, respectively. Thirdly, four branches have been selected from these areas under this zone. These four branches are Dhunat, Gabtali, Nandigram and Sarikandin, respectively. There are eight centres under these four branches of Grameen Bank randomly. These four branches are presented in Appendix A in Figure 1.2. Brief description of major information about four branches under two areas of GB that the total number of clients in these four branches was 23231 ( 259 male numbers and 22972 female numbers) in 2008 which increased to 23477 (306 male numbers and 23477 female numbers) in 2016. Distributed loan amount by these branches was Tk.4239.61 lac in 2008, which decreased to Tk.4018.7 lac in 2016. In this context, they provided education loan which was 52.0 lac Tk. among 210 education loanees in 2016. Amount of loan distribution was 0.93 lac Tk. among 135 struggle number of members in 2016 according to collected information from four branches of Grameen Bank severally, Bogra, 2016.

\subsection{Materials and Method}

The present study has been used a comparison of the socio-economic condition of borrower households of microfinance scheme before joining in Grameen Bank and at present. Both primary and secondary data have been used for the present study. To estimate the socio-economic impacts microfinance of GB on borrower households in the study area, the researcher has mainly used primary data, although secondary data have been used which are obtained from branch and zonal offices of GB. Primary data of this study have been collected in order to achieve these objectives for this study. To collect primary data from the borrowers of GB, eight centres from the four branches under two areas have been selected through purposive sampling. The total sample size was only 168 respondents through simple random sampling. The collected data were estimated using statistical techniques. Statistical analyses include mean, analysis of variance (ANOVA) test and Likert scales (four point-scales) such as Strongly increase (Strongly Agree), Moderate increase 
(Agree), Unchanged (Disagree) and Decreased (Strongly Disagree). They are used in order to summarize and interpret the data regarding socio-economic condition of the selected borrowers of GB. The borrowers showed the level of changes in 16 chosen indicators separately. Participation Impact Score (PIS) of selected change items show how much changes have occurred among the women borrowers after joining in GB. The possible PIS of any change item ranged from a minimum of 168 to 672 . In order to make meaningful comparison of data, the PIS for a particular change item was standardized by using the following formula (Labani et al., 2015). The formula can be written such as

Standardized PIS $($ SPIS $)=\left(\frac{\text { Obserbved participation impact score }}{\text { Possible participation impact score }} \times 100\right)$

\section{Empirical Results of the Study}

Empirical results of the study show in some sub-sections that are below as:

\subsection{Socio-economic Effects of Microfinance of Grameen Bank on Borrower Households}

The socio-economic status of all borrowers of GB is not the same in the study area. These features from borrower to borrower are varied. Most of the borrowers of Grameen Bank are less educated or uneducated people whose income, savings, asset's value are about near to the ground. A major part of GB borrowers are employed in household activities but they do not have contribution directly in increase on economic activities. Most of the borrowers depend on farm and non-farm related activities. But their land ownership is not mentionable and for this, a part of them are being transformed from farming activities to non-farm activities after joining in GB. After joining in GB, average change of socio-economic of borrower households shows in Appendix B in Table 1.1. It is found that total loan of borrower households increased about Tk. 19034.75 which indicates net change after joining in GB. It may be that most of the borrowers employed taking loan from GB in income generating activities after joining in GB. The Table shows that net change of average monthly income and expenditure are Tk. 1009.18 and Tk. 726.58, respectively. It reveals that net change of total savings and value of borrower household assets are Tk. 1405.83 and Tk. 8087.7, respectively. The table indicates that socio-economic status of borrower households have become change positively and improved after joining in GB due to increasing economic activities. On the other hand, family size of borrower households became change negatively and decreased it after joining in GB for social conscious.

\subsection{Net Socio-economic Effects of Microfinance of Grameen Bank on Borrower Households}

This study investigates socio-economic effects that indicate change in their income, expenditure, education, occupation of borrowers, savings, and asset value of borrower households. The changes of these socio-economic factors are analyzed as below:

\subsubsection{Average Change in Monthly Income of the Borrower Households}

Income of borrower households is one important indicator of economic condition. Poverty is measured by income or poverty line among borrowers who are poor or non-poor. Average monthly 
income of borrower households before involvement with GB and at present is found in Appendix B in Table 1.2. It shows that about 14.16 percent of borrower households have change average monthly income after taking microcredit from GB, and whose income level was below TK. 2500. It is shown in the table that before joining in GB, the highest percent of the borrower households had income in the range of TK. 2501-5000, and at present, 41.4 percent of borrower households have income between in Tk. 5001-7500. The table shows that the highest level of average monthly income between in Tk. 12501- above, and it was only 3.5 percent at present and in this income level there had no income of borrower households before joining in GB.

\subsubsection{Average Change in Monthly Expenditure of the Borrower Households}

Most of the people are poor whose average monthly expenditure is low due to low income in the rural area of the study area of Bangladesh. Average change in average monthly expenditure is shown in Appendix B in Table 1.3 that before joining in GB, about 7.07 percent of borrower households have expenditure monthly in range of below TK. 1500, and at present only one percent of borrower households has expenditure at this level. The table reveals that the highest (42.93) percent of borrower households had expenditure in the range of Tk. 1501-3000, and at present, above 34 percent of borrower households have average monthly expenditure between in TK. 30014500. Based on the table, it indicates that average monthly expenditure of borrower households are being increased after involving in GB.

\subsubsection{Average Change in Occupation of Borrowers}

Borrowers of Grameen Bank are employed in various occupations such as household service, day labour, petty business, weaving, and others beside household activities. Average changes in occupation of the borrowers are shown in Appendix B in Table 1.4 that nearly 84.8 percent of borrower's occupations were only in household service before joining in GB. At present, about 72.2 percent of borrower's occupations are only in household services. About 12.6 percent of borrower's occupation changed it after joining in GB. It indicates the net effect of borrower's occupation, and they employ in income generating activities such as petty business, embroidery, weaving, poultry raisings and others beside household activities

\subsubsection{Average Change in Total Savings of the Borrower Households}

It is found that savings of borrower households was increased after joining to GB. At present and before joining in GB, the savings pattern of borrower households is presented in Appendix B in Table 1.5. Borrowers can invest or expend it when they feel needy time. Before joining in GB, about 41.0 percent of borrower households did not have savings, and it indicates that the highest percent of borrowers had no savings in house or bank. Before joining in GB, the lowest percent of borrower households had savings in the range of Tk.9001-10500, but in this rage of savings at present, 5.6 percent of borrower households have savings. The table provides that before joining in GB, 9.1 percent of borrower households had savings in range of Tk. 4501-6000. But at present 24.8 percent of borrower households have savings between in Tk. 4501-6000. It indicates that above 15 percent of borrower households were able to increase their savings in this level after involving with GB. 


\subsubsection{Average Change in Amount of Loan of Borrower Households}

GB provides loan to poor women for income generating activities without any type of collateral, and those poor people have no access to conventional banks or financial institutions. The scenario of distribution of borrower households is shown in Appendix B in Table 1.6 that about 75.8 percent of borrower households have not taken any loan from GB with other institutions. The table shows that the highest percent (40.4) of borrower households from GB take loan in the range of Tk. 8001-16000 at present. But before joining in GB, only 9.1 percent of respondent households took credit in this level of loan. It is found that 21.2 percent, 11.1 percent and 5.0 percent of borrower households have taken loan from GB in range of TK. 24001-32000; TK. 32001-40000, and TK. 40001-above, respectively. But there were not respondents like to taken loan in those level of loan before involving in GB. Microcredit of GB has contribution on income generating activities and its effect on increasing income, savings and expenditure after taking loan (Bhuiya et al., 2016).

\subsubsection{Average Change in Total Asset Value of Borrower Households}

Assets of borrower households are calculated only in cash value. Here, as asset of borrower households is considered non-land assets like cattle, auto-rickshaw, sewing machine, shop, tractor, fishing net, boat, mobile-phone, television, fridge, $\mathrm{CD}$ player, furniture, etc. Average change in asset value of borrower households is shown in Appendix in Table 1.7 that about 26.3 percent of borrower households improved average change of asset value and transformed in the range of different levels such as Tk. 44001-55000; 55001-66000 and 66001-above, respectively, of borrower households. After joining in GB, the net average asset value of these borrower households was increased for buying various non-land assets such furniture. It is found in Table 1.7 that after joining in GB, about 7.5 percent and 4.6 percent net average change of borrower households was increased asset value between in Tk. 55001-66000 and 66001-above, respectively.

\subsection{Results of One-Way ANOVA test Analysis (Amount of Microcredit of Grameen Bank and Socio-economic Factors)}

In the present study, ANOVA test as statistical tools shows that there is statistically significant correlation between amount of microcredit and socio-economic factors such as level of education, occupation, size of family, number of income earners, average monthly income, average monthly expenditure, savings of borrower households, total asset value of borrower households, cultivated land and length of membership with GB. The results of the ANOVA tests are presented in Appendix B in Table 1.8.

\subsection{Distribution of Borrowers in terms of Effect of GB's Microcredit for Increase Economic Activities at Present}

After taken microfinance from Grameen Bank, most of the borrowers were employed more in income generating activities beside household activities. At present, it has a positive contribution to participation in household decision making, disbursed a part of income for children's education and with its other factors. It is shown in Appendix B in Table 1.9 about the distribution of borrowers in terms of effect of microcredit of GB to increase economic activities. 


\subsection{Result of Participation Impact Score (PIS) and SPIS}

To investigate the changes in 16 selected indicators of borrowers after taking loan from GB due to increase economic activities beside household activities that is shown in Appendix B in Table 1.10. The results of participation impact score (PIS) is shown that how much changes have occurred among borrowers after joining in GB for increase economic activities. Rank order was made based on total scores attained from ranking of borrowers. The possible PIS of any change item ranged from a minimum 168 to maximum 672. Standardized PIS (SPIS) $=\left(\frac{7560}{10752}\right) \times 100$ $=70.31$. Result of Standardized PIS (SPIS) indicates overall significant that is 70.31 percent. After evaluating among results of PIS or SPIS, socio-economic effects of microfinance of GB have been ranked from highest 542 (PIS) ( $1^{\text {st }}$ rank) indicated 80.65 percent (SPIS) for improved participation in family decision-making to lowest 396 (PIS) (16 ${ }^{\text {th }}$ rank) indicated 58.93 percent for improved counting ability.

\section{Conclusion and Some Recommendations}

From the data analysis of socio-economic and demographic feature it is shown that most of the borrowers have different education, income, income earning member, expenditure, savings, asset, and housing condition, etc. These have links with microcredit borrowing and in turn socioeconomic change. Most of the socio-economic features of borrowers are statistically significant with amount of loan at present that is tested by ANOVA tests. It is also found that socio-economic conditions of the borrowers have improved more at present compared to before involving with GB. The borrowers took microcredit from GB and used it in productive sectors and it is found that socio-economic have mentionable improved in the present study area. Some recommendations presents below as:

- Firstly, Most of the borrowers are uneducated and less educated women. Microfinance institutions should organize more training and education oriented programmes.

- Secondly, loan size is small that is not sufficient for any capital generating business such dairy farm. The microfinance institutions should extend loan size rationally and quickly.

- Lastly, the institution should set up rate of interest compared to commercial banks. Installment should start at least two months later. Government should provide some special facilitates and encourage microfinance institutions so that they provide loan and financial service to energetic and poor people who are agree to employ themselves in income generating activities. 


\section{APPENDICES}

\section{Appendix A: Figure}

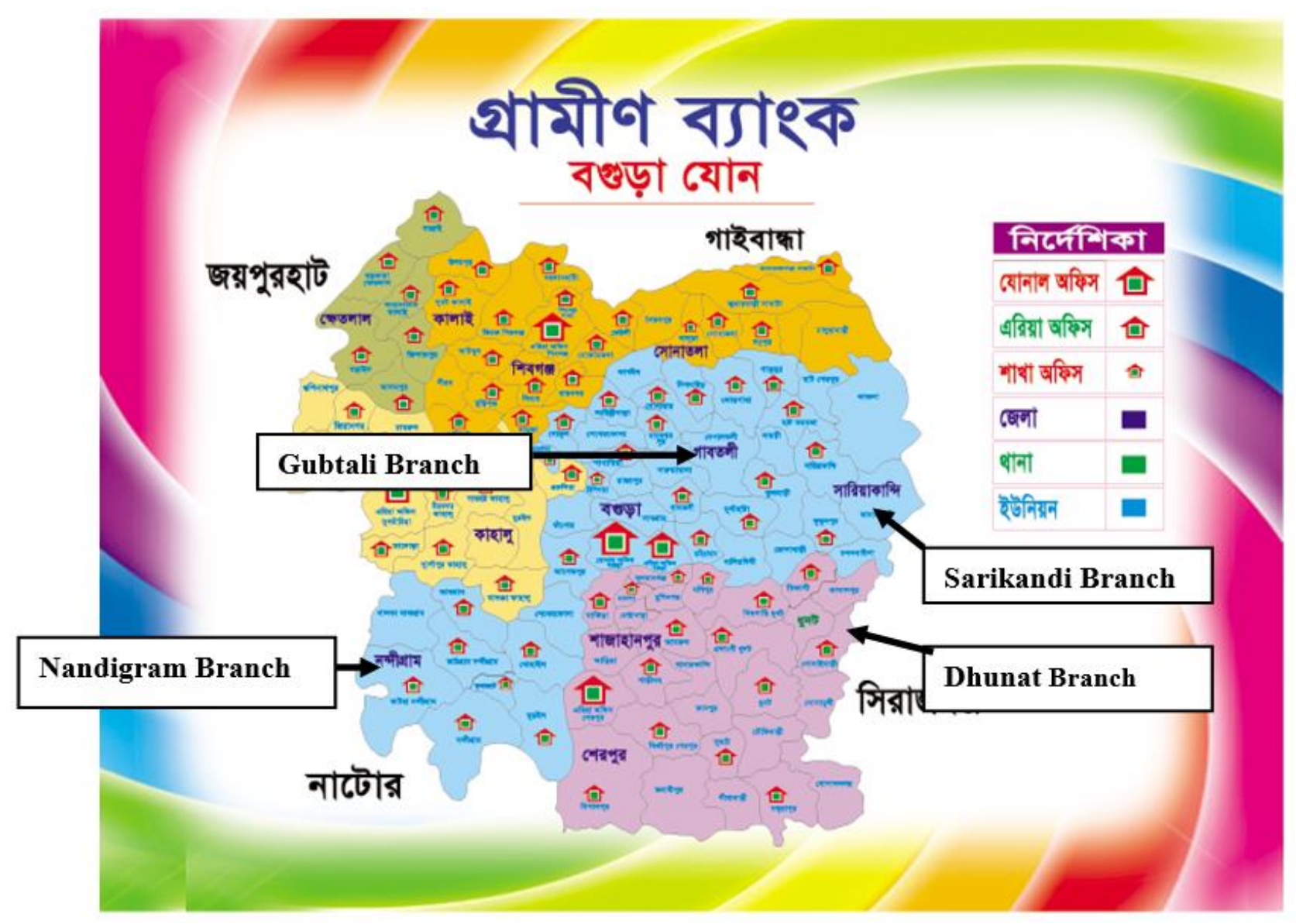




\section{Appendix B: Tables}

Table 1.1: Average change of Socio-economic Factors

\begin{tabular}{|l|l|l|l|}
\hline \multirow{2}{*}{ Main Socio-economic Variables } & Before of Joining in GB & At Present & Net change \\
\cline { 2 - 4 } & \multicolumn{1}{|c|}{ Mean } & \multicolumn{1}{c|}{ Mean } & \multicolumn{1}{c|}{ Mean } \\
\hline Average level of education of family & 7.62 & 8.79 & 1.17 \\
\hline Family Size & 3.91 & 3.19 & -0.72 \\
\hline Total Income earners in the family & 1.71 & 1.73 & 0.02 \\
\hline $\begin{array}{l}\text { Total female income earners in the } \\
\text { family }\end{array}$ & 0.15 & 0.24 & 0.09 \\
\hline Number of Livestock & 0.99 & & \\
\hline Average monthly income & 5558.79 & 1.39 & 0.4 \\
\hline Average monthly expenditure & 4404.50 & 6567.97 & 1009.18 \\
\hline Total savings & 1961.87 & 5132.08 & 726.58 \\
\hline Amount of loan & 1975.25 & 3369.70 & 1405.83 \\
\hline Value of household assets & 32853.5 & 21010.0 & 19034.75 \\
\hline Total amount of land & 24.73 & 40941.2 & 8087.7 \\
\hline Housing Condition & 55.30 & 25.72 & 0.99 \\
\hline Health Status & 54.2 & 80.81 & 25.51 \\
\hline Source: Calculated from Field Survey Data, 2018 & 74.1 & 19.9 \\
\hline
\end{tabular}

Table 1.2: Average Change in Average Monthly Income of Borrower Households

\begin{tabular}{|l|l|l|l|}
\hline \multirow{2}{*}{$\begin{array}{c}\text { Average Monthly } \\
\text { Income (TK.) }\end{array}$} & \multicolumn{1}{|c|}{$\begin{array}{c}\text { Before } \\
\text { Respondents at } \\
\text { Percentage }\end{array}$} & $\begin{array}{c}\text { At Present } \\
\text { Respondents at } \\
\text { Percentage }\end{array}$ & \multirow{2}{*}{$\begin{array}{c}\text { Net change of } \\
\text { Respondents }\end{array}$} \\
\hline $0-2500$ & 15.66 & 1.5 & -14.16 \\
\hline $2501-5000$ & 55.56 & 23.2 & -32.36 \\
\hline $5001-7500$ & 18.69 & 41.4 & 22.71 \\
\hline $7501-10000$ & 7.07 & 24.2 & 17.13 \\
\hline $10001-12500$ & 3.03 & 6.1 & 3.07 \\
\hline 12501 -above & 0 & 3.5 & 3.5 \\
\hline Total & 100 & 100 & 0 \\
\hline Source: Field Survey, 2018 & & \\
\hline
\end{tabular}

Table 1.3: Average Change in Average Monthly Expenditure of Borrower Households

\begin{tabular}{|l|l|l|l|}
\hline \multirow{2}{*}{$\begin{array}{c}\text { Average Monthly } \\
\text { Expenditure }\end{array}$} & \multicolumn{1}{|c|}{$\begin{array}{c}\text { Before } \\
\text { Respondents at } \\
\text { Percentage }\end{array}$} & $\begin{array}{c}\text { At Present } \\
\text { Respondents at } \\
\text { Percentage }\end{array}$ & $\begin{array}{c}\text { Net change } \\
\text { of } \\
\text { respondents }\end{array}$ \\
\hline $00-1500$ & 7.07 & 1.0 & -6.07 \\
\hline $1501-3000$ & 42.93 & 27.3 & -15.63 \\
\hline $3001-4500$ & 36.87 & 34.8 & -2.07 \\
\hline $4501-6000$ & 9.59 & 29.3 & 19.71 \\
\hline $6001-7500$ & 3.54 & 3.5 & -0.04 \\
\hline $7501-$ above & 0 & 4.0 & 4.0 \\
\hline Total & 100 & 100 & \\
\hline Source: Field Survey, 2018 & & \\
\hline
\end{tabular}


Table 1.4: Average Change in Occupation of the Borrowers

\begin{tabular}{|l|l|l|l|}
\hline \multirow{2}{*}{ Occupations of Borrowers } & \multicolumn{1}{|c|}{ Before } & At Present & \multicolumn{1}{c|}{$\begin{array}{c}\text { Net change } \\
\text { of } \\
\text { Respondents }\end{array}$} \\
\cline { 2 - 4 } & $\begin{array}{c}\text { Respondents at } \\
\text { Percentage }\end{array}$ & $\begin{array}{c}\text { Respondents at } \\
\text { Percentage }\end{array}$ & -12.6 \\
\hline Only housewife & 84.8 & 72.2 & 1 \\
\hline Housewife and day labour & 6.1 & 7.1 & 2.5 \\
\hline Housewife and petty business & 7.1 & 9.6 & 2 \\
\hline Housewife and embroidery & 1.0 & 3.0 & 3 \\
\hline Housewife and weaving & 1.0 & 4.0 & 4 \\
\hline Housewife and poultry raising & 0 & 4.0 & 1 \\
\hline $\begin{array}{l}\text { Housewife and sweet } \\
\text { preparing }\end{array}$ & 0 & 1.0 & 0 \\
\hline Total & 100 & \\
\hline Source: Field Survey, 2018 & 100 & & \\
\hline
\end{tabular}

Table 1.5: Average Change in Total Savings of Borrower Households

\begin{tabular}{|l|l|l|l|}
\hline \multirow{1}{*}{ Total savings } & \multicolumn{1}{|c|}{$\begin{array}{c}\text { Before } \\
\text { Respondents at } \\
\text { Percentage }\end{array}$} & $\begin{array}{c}\text { At Present } \\
\text { Respondents at } \\
\text { Percentage }\end{array}$ & $\begin{array}{c}\text { Net change of } \\
\text { Respondents }\end{array}$ \\
\hline No savings & 41.0 & 0 & -41.0 \\
\hline $1-1500$ & 8.6 & 5.6 & -3.0 \\
\hline $1501-3000$ & 21.7 & 22.7 & 1.0 \\
\hline $3001-4500$ & 12.6 & 23.7 & 11.1 \\
\hline $4501-6000$ & 9.1 & 24.8 & 15.7 \\
\hline $6001-7500$ & 2.5 & 11.1 & 8.6 \\
\hline $7501-9000$ & 3.0 & 6.5 & 3.5 \\
\hline $9001-10500$ & 0.5 & 5.6 & 5.1 \\
\hline Total & 100 & 100 & 0 \\
\hline Source: Field Survey, 2018 & & \\
\hline
\end{tabular}

Table 1.6: Average Change in Amount of Loan of Borrower Households

\begin{tabular}{|c|c|c|c|}
\hline \multirow[b]{2}{*}{$\begin{array}{l}\text { Amount of } \\
\text { Loan (Tk.) }\end{array}$} & \multirow{2}{*}{$\begin{array}{c}\text { Before } \\
\text { Respondents at } \\
\text { Percentage }\end{array}$} & \multicolumn{2}{|c|}{ At Present } \\
\hline & & $\begin{array}{c}\text { Respondents at } \\
\text { Percentage }\end{array}$ & $\begin{array}{l}\text { Net change of } \\
\text { respondents }\end{array}$ \\
\hline 00 & 75.8 & 00 & -75.8 \\
\hline $0-8000$ & 14.6 & 6.1 & -8.5 \\
\hline $8001-16000$ & 9.1 & 40.4 & 31.3 \\
\hline $16001-24000$ & 0.5 & 16.2 & 15.7 \\
\hline $24001-32000$ & 0 & 21.2 & 21.2 \\
\hline $32001-40000$ & 0 & 11.1 & 11.1 \\
\hline 40001-above & 0 & 5.0 & 5 \\
\hline Total & 100 & 100 & \\
\hline
\end{tabular}


Table 1.7: Average Change in Asset Value of Borrower Households

\begin{tabular}{|l|l|l|l|}
\hline \multicolumn{1}{|c|}{$\begin{array}{c}\text { Asset value } \\
\text { (TK.) }\end{array}$} & \multicolumn{1}{|c|}{$\begin{array}{c}\text { Before } \\
\text { Respondents at } \\
\text { Percentage }\end{array}$} & \multicolumn{1}{c|}{$\begin{array}{c}\text { At Present } \\
\text { Respondents at } \\
\text { Percentage }\end{array}$} & $\begin{array}{c}\text { Net change of } \\
\text { respondents }\end{array}$ \\
\hline Below 11000 & 20.2 & 6.0 & -14.2 \\
\hline $11001-22000$ & 17.7 & 13.6 & -4.1 \\
\hline $22001-33000$ & 18.7 & 16.7 & -2.0 \\
\hline $33001-44000$ & 21.2 & 15.2 & -6.0 \\
\hline $44001-55000$ & 14.1 & 17.2 & 3.1 \\
\hline $55001-66000$ & 7.1 & 14.6 & 7.5 \\
\hline $66001-$ above & 1 & 5.6 & 4.6 \\
\hline Total & 100 & 100 & \\
\hline Source: Field Survey, 2018 & & \\
\hline
\end{tabular}

Table 1.8: ANOVA Test of Microcredit and Socio-economic factors

\begin{tabular}{|l|l|l|l|}
\hline Microcredit and socio-economic factors & df & F & Sig. \\
\hline Microcredit and Level of Education & 5 & 3.157 & 0.026 \\
\hline Microcredit and Occupation of Borrowers & 6 & 2.751 & 0.014 \\
\hline Microcredit and Size of Family of Borrowers & 5 & 2.507 & 0.032 \\
\hline Microcredit and Number of Income Earners in the Family & 4 & 8.697 & 0.000 \\
\hline Microcredit and Average Monthly Income & 6 & 3.020 & 0.008 \\
\hline Microcredit and Average Monthly Expenditure & 7 & 4.375 & 0.000 \\
\hline Microcredit and Savings of Borrowers' Household & 3 & 9.322 & 0.000 \\
\hline Microcredit and Value of Assets of the Households & 8 & 2.654 & 0.009 \\
\hline Microcredit and Cultivated Land by Borrowers & 6 & 2.847 & 0.011 \\
\hline Microcredit and Length of membership with GB & 6 & 5.019 & 0.000 \\
\hline Poverty and Housing Condition & 6 & 1.891 & 0.084 \\
\hline Microcredit and Health Status & 4 & 5.410 & 0.000 \\
\hline Source: Calculated from Field Survey Data, 2018 & & & \\
\hline
\end{tabular}

Table 1.9: Distribution of Borrowers in terms of Effect of Microcredit of GB for Economic Activities at Present (Changing borrower numbers and percentage)

\begin{tabular}{|c|c|c|c|c|c|c|}
\hline Sn. & Impact on indicators & $\begin{array}{c}\text { Strongly } \\
\text { increase (4) } \\
\end{array}$ & $\begin{array}{c}\text { Moderate } \\
\text { increase (3) } \\
\end{array}$ & $\begin{array}{c}\text { Unchanged } \\
(2)\end{array}$ & $\begin{array}{c}\text { Decreased } \\
(\mathbf{1})\end{array}$ & $\begin{array}{c}\text { Total } \\
\text { Change } \\
\end{array}$ \\
\hline \multirow[t]{2}{*}{1} & \multirow{2}{*}{$\begin{array}{l}\text { Improved participation } \\
\text { in family decision- } \\
\text { making }\end{array}$} & 27 & 120 & 20 & 1 & 168 \\
\hline & & $16.1 \%$ & $71.4 \%$ & $11.9 \%$ & $0.6 \%$ & 100 \\
\hline \multirow[t]{2}{*}{2} & \multirow{2}{*}{$\begin{array}{l}\text { Improvement } \\
\text { clothing status }\end{array}$} & 33 & 85 & 50 & 0 & 168 \\
\hline & & $19.6 \%$ & $50.6 \%$ & $29.6 \%$ & $0 \%$ & 100 \\
\hline \multirow[t]{2}{*}{3} & \multirow{2}{*}{$\begin{array}{l}\text { Increased in children } \\
\text { education expenditure }\end{array}$} & 20 & 82 & 46 & 20 & 168 \\
\hline & & $11.9 \%$ & $48.8 \%$ & $27.4 \%$ & $11.9 \%$ & 100 \\
\hline \multirow[t]{2}{*}{4} & \multirow{2}{*}{$\begin{array}{l}\begin{array}{l}\text { Improved access to } \\
\text { society }\end{array} \\
\end{array}$} & 19 & 79 & 63 & 7 & 168 \\
\hline & & $11.3 \%$ & $47.0 \%$ & $37.5 \%$ & $4.2 \%$ & 100 \\
\hline \multirow[t]{2}{*}{5} & \multirow{2}{*}{$\begin{array}{l}\text { Improvement in } \\
\text { society's attitude to own }\end{array}$} & 20 & 103 & 39 & 6 & 168 \\
\hline & & $11.9 \%$ & $61.3 \%$ & $23.2 \%$ & $3.6 \%$ & 100 \\
\hline
\end{tabular}


DOI: 10.5281/zenodo.3234796

\begin{tabular}{|c|c|c|c|c|c|c|}
\hline \multirow[t]{2}{*}{6} & \multirow{2}{*}{$\begin{array}{lll}\text { Improved access to } \\
\text { treatment }\end{array}$} & 32 & 83 & 49 & 4 & 168 \\
\hline & & $19.0 \%$ & $49.4 \%$ & $29.2 \%$ & $2.4 \%$ & 100 \\
\hline \multirow[t]{2}{*}{7} & \multirow{2}{*}{$\begin{array}{l}\text { Improved } \\
\text { understanding ability }\end{array}$} & 26 & 103 & 39 & 0 & 168 \\
\hline & & $15.5 \%$ & $61.3 \%$ & $23.2 \%$ & $0 \%$ & 100 \\
\hline \multirow[t]{2}{*}{8} & \multirow{2}{*}{$\begin{array}{l}\text { Increased reading } \\
\text { ability }\end{array}$} & 2 & 60 & 106 & 0 & 168 \\
\hline & & $1.2 \%$ & $35.7 \%$ & $63.1 \%$ & $0 \%$ & 100 \\
\hline \multirow[t]{2}{*}{9} & \multirow{2}{*}{$\begin{array}{ll}\text { Increased } & \text { writing } \\
\text { ability } & \end{array}$} & 2 & 74 & 92 & 0 & 168 \\
\hline & & $1.2 \%$ & $44.0 \%$ & $54.8 \%$ & $0 \%$ & 100 \\
\hline \multirow[t]{2}{*}{10} & \multirow{2}{*}{$\begin{array}{l}\text { Increased participation } \\
\text { with social activities }\end{array}$} & 43 & 99 & 24 & 2 & 168 \\
\hline & & $25.6 \%$ & $58.9 \%$ & $14.3 \%$ & $1.2 \%$ & 100 \\
\hline \multirow[t]{2}{*}{11} & \multirow{2}{*}{$\begin{array}{l}\text { Improved relation with } \\
\text { husband }\end{array}$} & 38 & 89 & 30 & 11 & 168 \\
\hline & & $22.6 \%$ & $53.0 \%$ & $17.9 \%$ & $6.5 \%$ & 100 \\
\hline \multirow[t]{2}{*}{12} & \multirow{2}{*}{$\begin{array}{l}\text { Improved relation with } \\
\text { relatives }\end{array}$} & 33 & 94 & 39 & 2 & 168 \\
\hline & & $19.6 \%$ & $56.0 \%$ & $23.2 \%$ & $1.2 \%$ & 100 \\
\hline \multirow[t]{2}{*}{13} & \multirow{2}{*}{$\begin{array}{l}\text { Improved relation with } \\
\text { neighbour }\end{array}$} & 26 & 85 & 51 & 6 & 168 \\
\hline & & $15.5 \%$ & $50.6 \%$ & $30.4 \%$ & $3.6 \%$ & 100 \\
\hline \multirow[t]{2}{*}{14} & \multirow{2}{*}{$\begin{array}{l}\text { Increased participation } \\
\text { in social events }\end{array}$} & 38 & 91 & 36 & 3 & 168 \\
\hline & & $22.6 \%$ & $54.2 \%$ & $21.4 \%$ & $1.8 \%$ & 100 \\
\hline \multirow[t]{2}{*}{15} & \multirow{2}{*}{$\begin{array}{l}\text { Improved physical } \\
\text { movement }\end{array}$} & 19 & 119 & 29 & 1 & 168 \\
\hline & & $11.3 \%$ & $70.8 \%$ & $17.3 \%$ & $0.6 \%$ & 100 \\
\hline \multirow[t]{2}{*}{16} & \multirow{2}{*}{$\begin{array}{l}\text { Improved counting } \\
\text { ability }\end{array}$} & 8 & 95 & 65 & 0 & 168 \\
\hline & & $4.8 \%$ & $56.5 \%$ & $38.7 \%$ & $0 \%$ & 100 \\
\hline
\end{tabular}

Table 1.10: Effect of Participation Items of the Borrower Households Following PIS at Present

\begin{tabular}{|l|l|l|l|l|l|}
\hline Sn. & Effect on indicators & PIS & SPIS & \% & Rank \\
\hline 1 & Improved participation in family decision-making & 542 & 80.65 & 7.17 & 1 \\
\hline 2 & Improved physical movement & 524 & 77.98 & 6.93 & 2 \\
\hline 3 & Increased participation with social activities & 519 & 77.23 & 6.86 & 3 \\
\hline 4 & Increased participation in social events & 500 & 74.40 & 6.61 & 4 \\
\hline 5 & Improved relation with relatives & 494 & 73.51 & 6.53 & 5 \\
\hline 6 & Improved understanding ability & 491 & 73.07 & 6.49 & 6 \\
\hline 7 & Improved relation with husband & 490 & 72.92 & 6.48 & 7 \\
\hline 8 & Improvement in clothing status & 487 & 72.47 & 6.44 & 8 \\
\hline 9 & Improved access to treatment & 479 & 71.28 & 6.34 & 9 \\
\hline 10 & Improvement in society's attitude to own & 473 & 70.39 & 6.26 & 10 \\
\hline 11 & Improved relation with neighbour & 467 & 69.49 & 6.18 & 11 \\
\hline 12 & Improved access to society & 446 & 66.37 & 5.89 & 12 \\
\hline 13 & Increased in children education expenditure & 438 & 65.18 & 5.79 & 13 \\
\hline 14 & Increased writing ability & 414 & 61.61 & 5.48 & 14 \\
\hline 15 & Increased reading ability & 400 & 59.52 & 5.29 & 15 \\
\hline 16 & Improved counting ability & 396 & 58.93 & 5.24 & 16 \\
\hline Source: Calculated from Field Survey Data, 2018 & & & & \\
\hline
\end{tabular}




\section{References}

[1] Alam, Muhammad, et al. "Impact of Microcredit Scheme on Socio-economic Status of Farmers (A case study of PRSP in District Gujranwala)." South Asian Studies 29.1 (2014): 161.

[2] Bangladesh Economic Review (BER), (2017 \& 2018)

[3] Bhuiya, Mohammad Monzur Morshed, et al. "Impact of microfinance on household income and consumption in Bangladesh: empirical evidence from a quasi-experimental survey." The Journal of Developing Areas 50.3 (2016): 305-318.

[4] Bogra Zonal Office, Grameen Bank and Annual Report, 2008-2016.

[5] Clement, Latio Kudus. "Socio-economic impact of microfinance in post conflict situation: A case of SUMI in Juba County Sudan." Unpublished Master Thesis submitted to University of Khartoum (2010).

[6] Dzisi, Smile, and Francis Obeng. "Microfinance and the socio-economic wellbeing of women entrepreneurs in Ghana." International Journal of Business and Social Research 3.11 (2013): 45-62.

[7] Grameen Bank (GB) Annual Report (2000- 2016)

[8] Khan, S., Khan, H., Azeem, A., Islam, Z. and Rehman, N. U. "The role of micro credit in poverty alleviation". Journal of Poverty, Investment and Development an International Peer-reviewed Journal, (2017), ISSN 2422-846X.

[9] Kireti, Grace Wakio, and Maurice Sakwa. "Socio-Economic Effects of Microfinance Services on Women: The Case of Rosewo Microfinance, Nakuru County, Kenya." International Journal of Academic Research in Economics and Management Sciences 3.3 (2014): 43.

[10] Kireti, Grace Wakio, and Maurice Sakwa. "Socio-Economic Effects of Microfinance Services on Women: The Case of Rosewo Microfinance, Nakuru County, Kenya." International Journal of Academic Research in Economics and Management Sciences 3.3 (2014): 43.

[11] Labani, S. A., M. Z. Islam, and A. S. M. G. Hafeez. "Socio-economic Impact of Grameen Bank Income Generating Loans on Rural Women of Tangail District." Journal of Environmental Science and Natural Resources 8.2 (2015): 135-139.

[12] Labour Force Survey (LFS) of Bangladesh -2010

[13] Littlefield, E., Morduch, J. and Hashemi, S. "Is micro finance an effective strategy to reach the Millennium Development Goals?" (2003) Focus Note No. 24

[14] Luyirika, Martha Nakakuta. The role of microfinance in the socio-economic development of women in a community: a case study of Mpigi Town Council in Uganda. Diss. 2010.

[15] Patient, M. G., Mbabazize, M. and Charles, R. "Effect of microfinance services on women socio economic development: A case study of Tumba microfinance in Huye District, Rwanda" European Journal of Business and Social Sciences, (2016) Vol. 5, No. 06, P.P. 185 - 200, ISSN: 2235 -767X

[16] Paul, D. C., and M. Saadullah. "Role of women in homestead of small farm category in an area of Jessore, Bangladesh." Livestock Research for Rural Development 3.2 (1991): 2329.

[17] Reji, E. M. "Socio-Economic Impact of Microfinance: A Study of Neighbhourhood Groups (NHGs) in Nilambur Block of Malappuram District, Kerala." Indian Journal of Agricultural Economics 64.902-2016-67300 (2009). 
[18] Saad, Ahmad, Imtiaz Ahmad Waraich, and Mariah Ijaz. "Socio-Economic Effects of Microfinance on Agricultural Sector: An Analysis of Farmer's Standard of Life in Multan." International Review of Management and Business Research3.3 (2014): 1671.

[19] Velásquez Alcívar, Agustín Antonio. A socio economic study of microfinance in the Urban Informal Sector. MS thesis. Mánchester/Universidad de Manchester/2015, 2015.

[20] “The Micro-credit Summit: 1997” Declaration and plan of action, Washington, D.C. (1997)

*Corresponding author.

E-mail address: shamim07eco@gmail.com 